\title{
Histopathological Response of Milkfish Chanos chanos Forsskal Fingerlings to Potassium Permanganate*
}

\author{
Erlinda R. CRUZ and Catherine T. TAMSE \\ Pathology Laboratory, Aquaculture Department, Southeast \\ Asian Fisheries Development Center \\ Tigbauan, Iloilo, Philippines
}

(Received November 16, 1985)

\begin{abstract}
Static $96 \mathrm{~h}$ bioassays were conducted on milkfish fingerlings at concentrations ranging from 1.00 to $1.80 \mathrm{mg} / l \mathrm{KMnO}_{4}$. Histopathological analyses of gills, liver, and kidney tissues revealed significant changes even in non-lethal concentrations tested. Damage became severe with increasing concentration and longer exposure to the chemical. Partial to complete recovery was observed in gills, liver, and kidney cells of fish exposed to $\mathrm{KMnO}_{4}$ for $96 \mathrm{~h}$ and then maintained in $\mathrm{KMnO}_{4}$-free seawater for $240 \mathrm{~h}$.
\end{abstract}

Potassium permanganate $\left(\mathrm{KMnO}_{4}\right)$, a strong oxidizing agent, has long been used in aquatic systems for various purposes. These include improvement of available oxygen in water (LAY, 1971; TUCKER and BOYD, 1977), treatment of infectious diseases (PHELPs et al., 1977; TUCKER and Boyd, 1977; JEE and PLUMB, 1981), detoxification of fish poisons (LAWRENCE, 1956; MARKING and BILLS, 1975), and control of algae (LAY, 1971; TUCKer and Boyd, 1977). The use of $\mathrm{KMnO}_{4}$ for certain aquatic applications has been approved by the United States Food and Drug Administration (MEYER et al., 1976).

Although $\mathrm{KMnO}_{4}$ has been used extensively, available literature on tolerance level to fish is limited and none on histopathological effects on fish tissues.

This study describes the histopathological response of milkfish, Chanos chanos, fingerlings exposed to different concentrations of $\mathrm{KMnO}_{4}$.

\section{Materials and Methods}

Milkfish fingerlings (3-5 g) were acclimatized for five days under laboratory conditions. Fish were fed daily with live brine shrimp (Artemia sp.) adults but were starved $24 \mathrm{~h}$ prior to and

\footnotetext{
* SEAFDEC Contribution No. 175.
}

during the experiment.

Static $96 \mathrm{~h}$ bioassays were conducted following standard procedures for toxicity tests (APHA, 1971). The completely randomized design (CRD) was used for the experiments. Tests were conducted in $50 l$ glass aquaria with $10 \mathrm{fish} / 30 l$ seawater (temperature, $27 \pm 1^{\circ} \mathrm{C}$; salinity, $30 \mathrm{ppt}$; $\mathrm{pH}, 8.4)$ with aeration. Test concentrations ranged from $1.0-1.80 \mathrm{mg} / l \mathrm{KMnO}_{4}$ plus a control. All test concentrations were done in three replicates.

The median lethal concentration (LC50) values at different time intervals are not included in this report, but will be presented in a separate paper.

Moribund or freshly dead fish were sampled after $24 \mathrm{~h}$ at the end of the experiment for histological analyses of the gills, liver, and kidney. Tissues were fixed in $10 \%$ buffered formalin, washed in running tapwater, dehydrated with ethyl alcohol, cleared in xylene, infiltrated with paraffin, and embedded in paraffin wax. Tissues were sectioned at $6 \mu$ and stained with hematoxylin and eosin.

All surviving fish after the $96 \mathrm{~h}$ exposure were transferred to a $\mathrm{KMnO}_{4}$-free seawater and maintained for another $240 \mathrm{~h}$. Fish were likewise sampled at the end of the $240 \mathrm{~h}$ period for histological analyses of the gills, liver, and kidney tissues. 


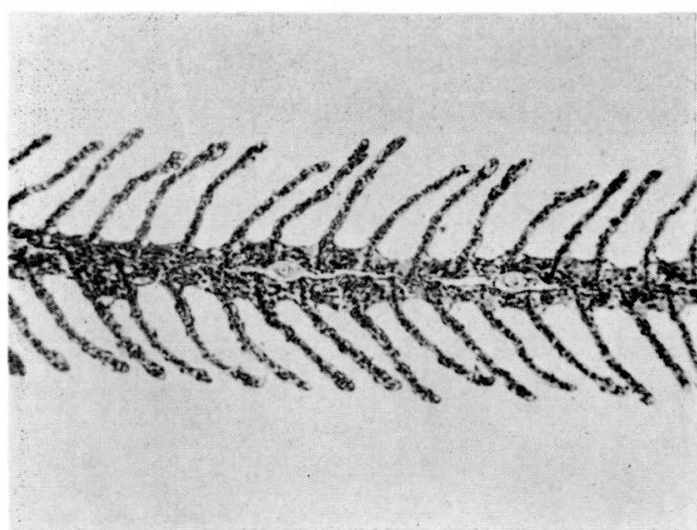

Fig. 1. Gill filament from control milkfish with normal gill lamellae. H \& E. $200 \times$.

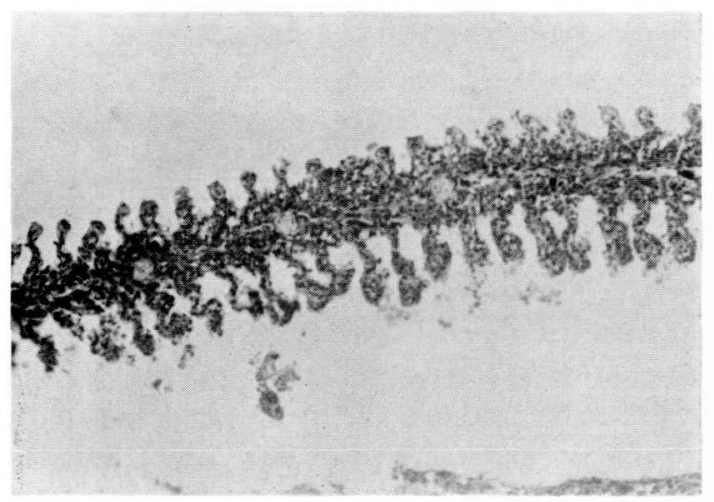

Fig. 2. Gill filament from milkfish exposed to 1.35 $\mathrm{mg} / \mathrm{l} \mathrm{KMnO}_{4}$ for $24 \mathrm{~h}$ showing lamellar hyperplasia. H \& E. $200 \times$.

\section{Results}

\section{Fish Behaviour}

Immediately upon exposure to $\mathrm{KMnO}_{4}$, all fish were affected even at concentrations that caused no mortality during the test. Fish exhibited rapid opercular movements and swimming activity. In fish exposed to higher concentrations, that behaviour continued for 30 minutes followed by gulping of water at the surface and blackening of the dorsal portion of the body. The snout and fin tips were clearly oxidized as evidenced by the brownish color. Fish affected by the chemical were less sensitive to external noise or movement.

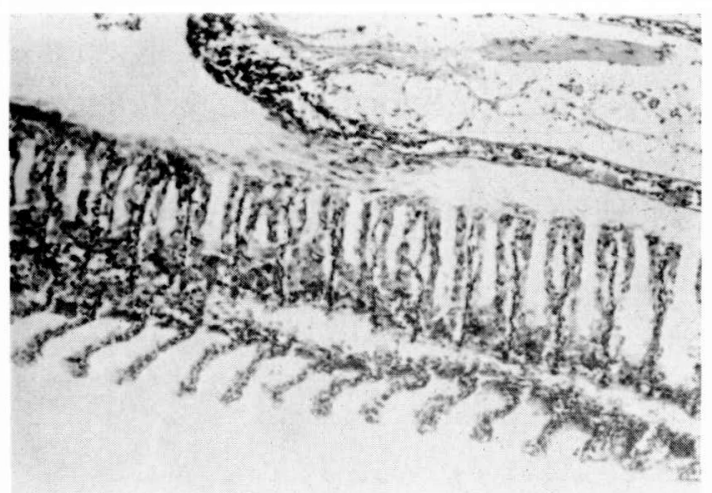

Fig. 3. Gill lamellae exposed to $1.4 \mathrm{mg} / / \mathrm{KMnO}_{4}$ for $24 \mathrm{~h}$ showing epithelial lifting. $\mathrm{H} \& \mathrm{E}$. $200 \times$.
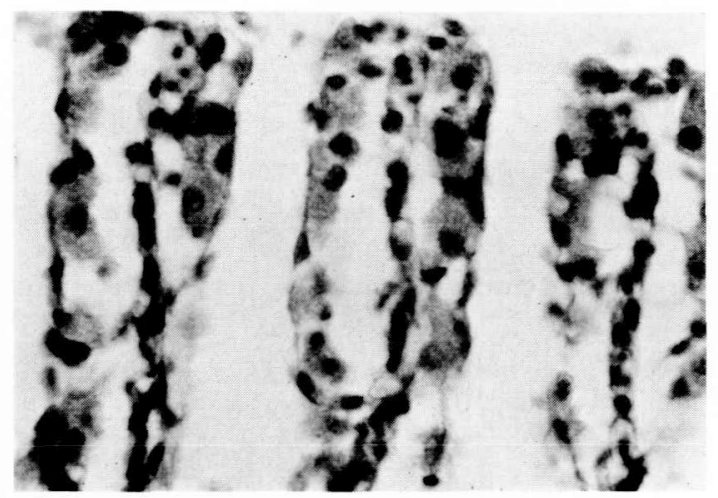

Fig. 4. High power view of Fig. 3. The epithelial layer lifted away from the pillar cell system. H \& E. $1000 \times$.

\section{Histopathology}

Histopathological changes in the gills liver, and kidney were observed in all treatments as early as $24 \mathrm{~h}$ after exposure. Lesions observed were essentially similar in all treatments and exposure time. However, tissue damage became severe with increasing concentrations and longer exposure to the chemical.

\section{Gills}

Fig. 1 shows normal structure of milkfish gill filament. Fish exposed to the chemical after $24 \mathrm{~h}$ exhibited epithelial hyperplasia (Fig. 2), clubbing of lamellar tips, fusion of adjacent lamellae, lamellar detachment, epithelial lifting (Figs. 3, 4), and extensive disruption of the gill system. 


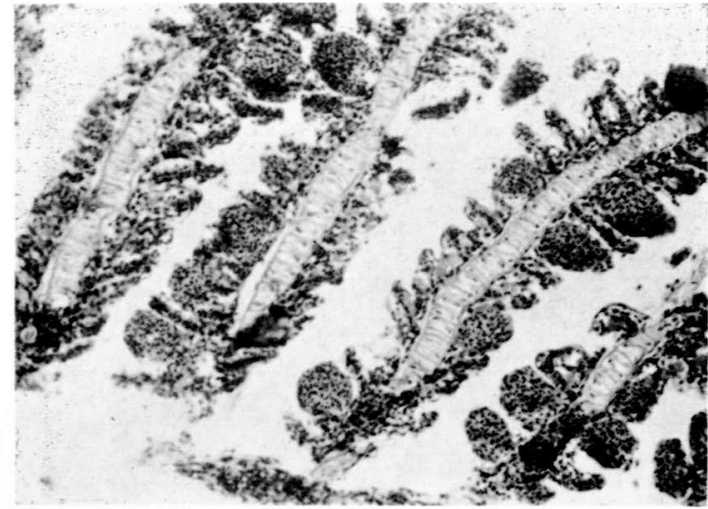

Fig. 5. Gill filaments exposed to $1.45 \mathrm{mg} / l \mathrm{KMnO}_{4}$ for $96 \mathrm{~h}$ with multiple aneurysms. $\mathrm{H} \& \mathrm{E}$. $100 \times$.

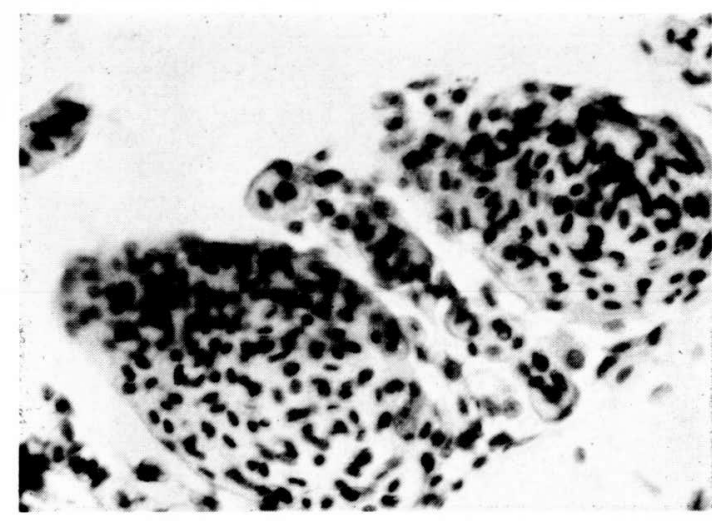

Fig. 6. Higher-power view of Fig. 5. Aneurysm contains disorganized mass of pillar cells and blood cells. H \& E. $1000 \times$.

After 96 h, gills had severe pathological changes. In many filaments, several lamellae exhibited bloodfilled aneurysms or lamellar telangiectases (Fig. 5). In each of these swollen and rounded secondary lamellae, the epithelium enclosed a disorganized mass of pillar cells and blood cells (Fig. 6). Severe hyperplasia of epithelium resulted in extensive fusion of lamellae (Fig. 7).

2. Liver

In control fish, the liver parenchyma is composed of polyhedral hepatocytes separated by sinusoids (Fig. 8). Following exposure to $\mathrm{KMnO}_{4}$, the liver parenchyma had undergone severe degeneration consisting of vacuolation and necrosis. Vacuolation of the hepatocytes was

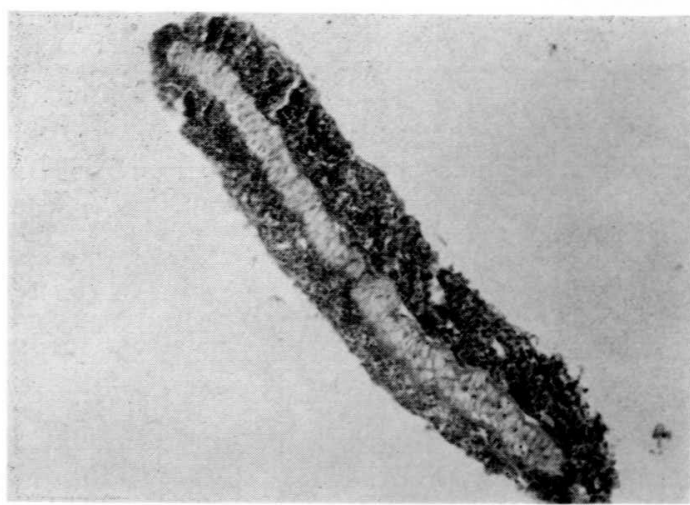

Fig. 7. Severe hyperplasia of gill epithelium resulted to fusion of lamellae after exposure to 1.80 $\mathrm{mg} / l \mathrm{KMnO}_{4}$ for $96 \mathrm{~h}$. $\mathrm{H} \&$ E. $200 \times$.

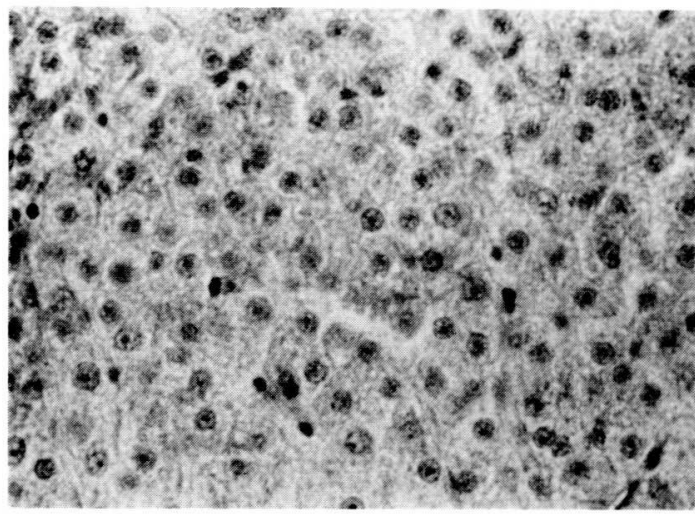

Fig. 8. Liver hepatocytes from control milkfish. H \& E. $1000 \times$.

observed in all treatments tested. Fish exposed to $1.80 \mathrm{mg} / l \mathrm{KMnO}_{4}$ exhibited extensive vacuolation of the hepatocytes (Fig. 9). Also, the welldefined liver structural pattern was lost. The extent of liver structure disruption generally corresponded to the degree of cytoplasmic vacuolation of the hepatocytes.

Necrotic lesions walled-off by thick layers of fibrin (Fig. 10) were also often noted. Liver cell nuclei were pyknotic and sinusoids were dilated (Fig. 11). Hemorrhagic areas were frequently seen, especially in blood vessels and sinusoids presumably demonstrating stasis (Fig. 12). In some, liver hepatocytes showed fibrosis (Fig. 13). 3. Kidney 


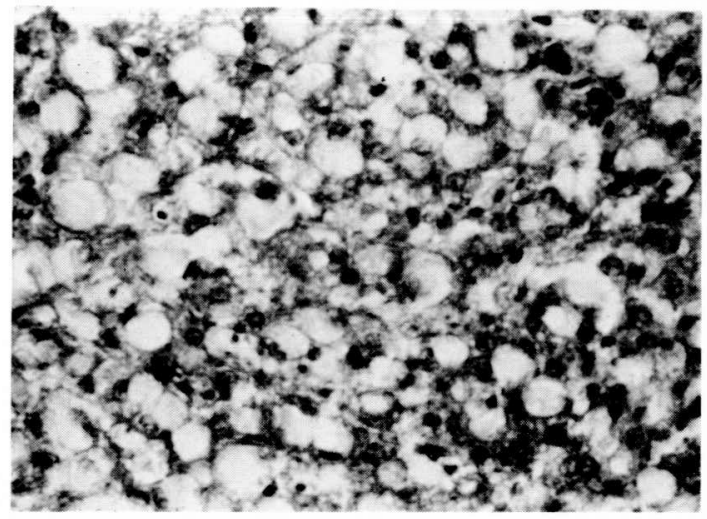

Fig. 9. Extensive vacuolation of hepatocytes after exposure to $1.80 \mathrm{mg} / l \mathrm{KMnO}_{4}$ for $24 \mathrm{~h}$. Vacuoles were of different sizes and shapes. The well-defined liver structure was also disrupted. H \& E. $1000 \times$.

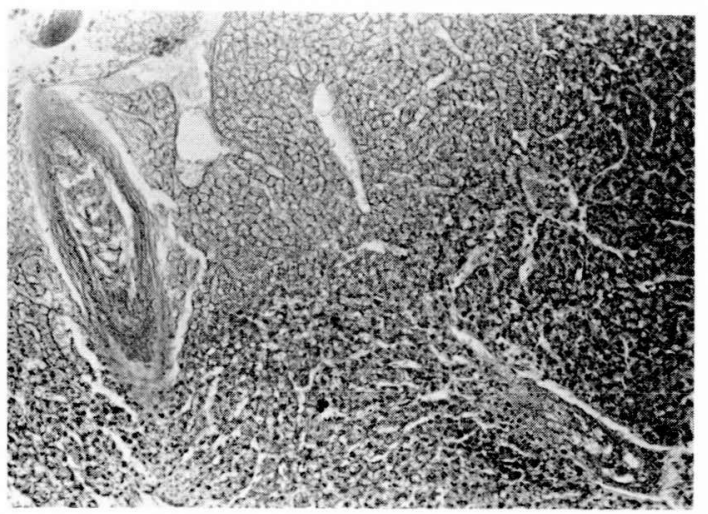

Fig. 10. Necrotic area is walled-off by thick layers of fibrin after exposure to $1.25 \mathrm{mg} / l$ $\mathrm{KMnO}_{4}$ for 24 h. $\mathrm{H} \&$ E. $200 \times$

The milkfish kidney is composed of the glomerulus, renal tubules and hematopoietic tissue (Fig. 14). A marked dilation of the glomerular capillaries and thickening of the walls occurred $24 \mathrm{~h}$ after exposure to the chemical (Fig. 15). In some, there was a consequent hypertrophy of the glomerulus and space of Bowman's capsule was not observed (Fig. 16). Also, some glomeruli were shrunken (Fig. 17).

Cloudy swelling (Fig. 18) and vacuolation (Fig. 19) of epithelial cells in the renal tubule were often observed. The shape of the affected cells were indistinguishable and the lumen of the tubules either decreased in size, or completely

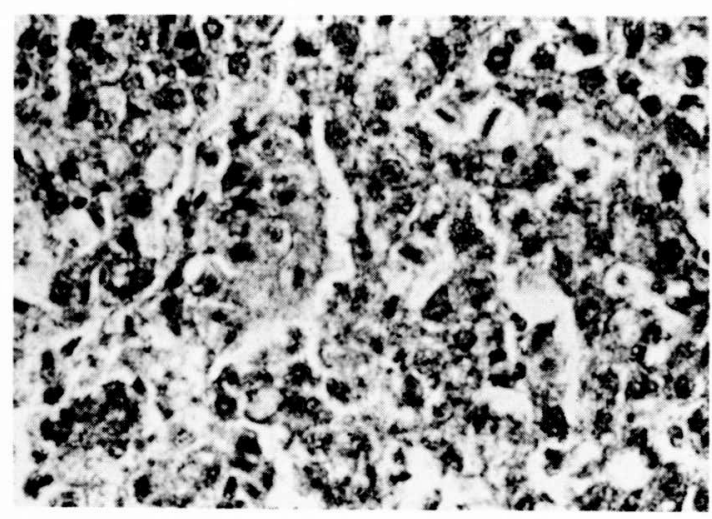

Fig. 11. Pyknotic nuclei and sinusoidal dilation were evident after exposure to $1.40 \mathrm{mg} / \mathrm{l}$ $\mathrm{KMnO}_{4}$ for 24 h. H \& E. $1000 \times$.

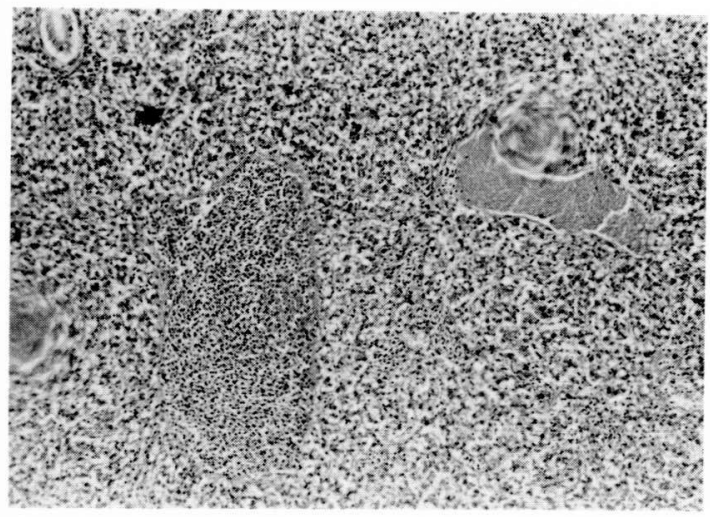

Fig. 12. Hemorrhage occurred in blood vessels and sinusoids after exposure to $1.25 \mathrm{mg} / \mathrm{l}$ $\mathrm{KMnO}_{4}$ presumably demonstrating stasis. H \& E. $200 \times$.

disappeared. Hemorrhage also occurred as erythrocytes consequently filled up the renal tubule. Recovery from $\mathrm{KMnO}_{4}$ induced lesions.

The gills, liver, and kidney of milkfish exposed to 1.0 to $1.50 \mathrm{mg} / l \mathrm{KMnO}_{4}$ for $96 \mathrm{~h}$ and then transferred to a $\mathrm{KMnO}_{4}$-free environment for $240 \mathrm{~h}$ apparently recovered. Most had normal gill structures (Fig. 20) although hyperplasia, clubbing, and some lamellar detachment were still evident. There was no fusion of adjacent lamellae, epithelial lifting, nor aneurysms observed. Although the liver exhibited vacuolation of the hepatocytes after $240 \mathrm{~h}$ in untreated seawater, vacuolation was less than in their coun- 


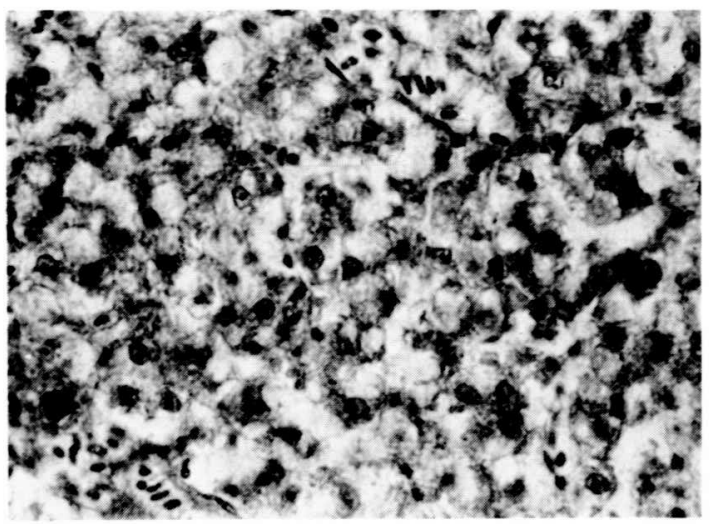

Fig. 13. Liver hepatocytes showing fibrosis after exposure to $1.0 \mathrm{mg} / l \mathrm{KMnO}_{4}$ for $24 \mathrm{~h}$. H \& E. $1000 \times$.

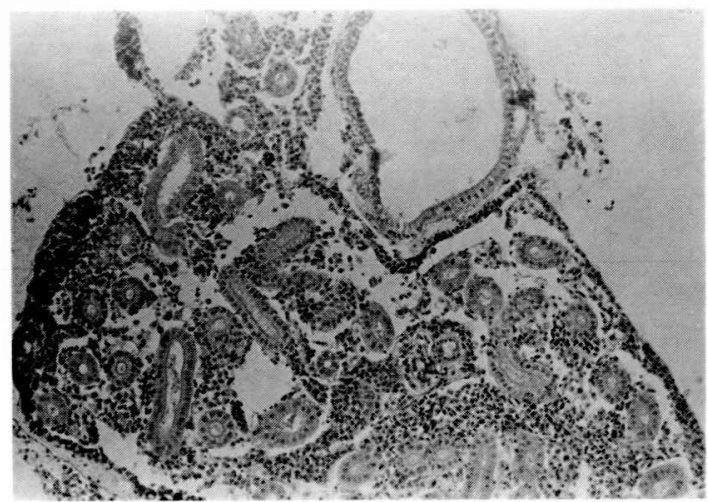

Fig. 14. Kidney from control fish showing glomerulus, renal tubules and hematopoietic tissue. $\mathrm{H} \& \mathrm{E} .100 \times$.

terparts prior to recovery (Fig. 21). The renal tubules appear to be normal after the $240 \mathrm{~h}$ recovery period (Fig. 22).

\section{Discussion}

Changes observed in milkfish behaviour during exposure to $\mathrm{KMnO}_{4}$ clearly indicate that the fish are under stress. Increased opercular rates have been suggested as a sensitive indicator of physiological stress in fish exposed to pollutants and may be caused by decreased efficiency in oxygen uptake or transport (DAvis, 1973; THOMAs and RiCE, 1975).

In fish, the gills, liver, and kidney are usually

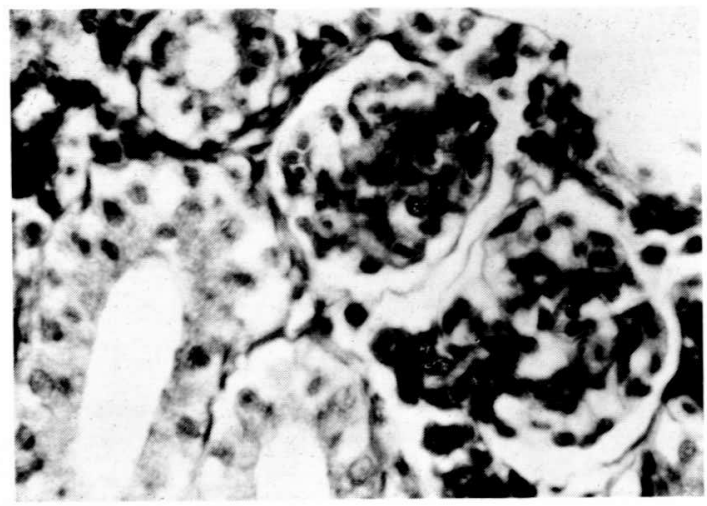

Fig. 15. Glomerulus from fish exposed to 1.35 $\mathrm{mg} / l \mathrm{KMnO}_{4}$ for $24 \mathrm{~h}$. Note dilation of the glomerular capillaries. H \& E. $1000 \times$.

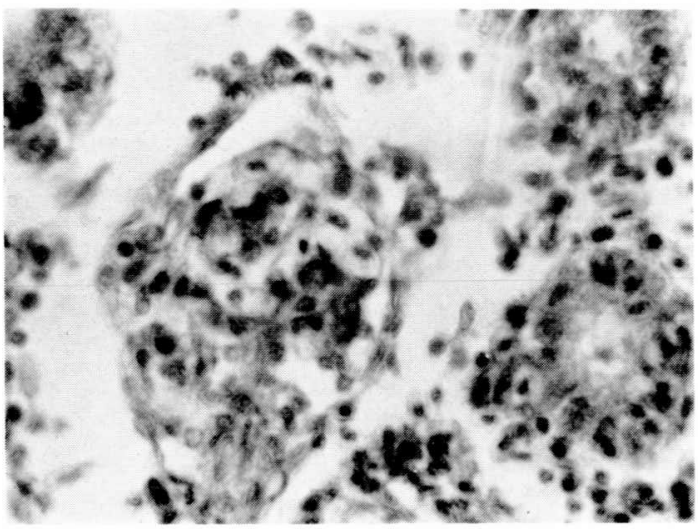

Fig. 16. Glomerulus from fish exposed to $1.0 \mathrm{mg} / \mathrm{l}$ $\mathrm{KMnO}_{4}$ for $96 \mathrm{~h}$. Glomerular capillaries were extremely dilated and space of Bowman's capsule was not observed. $\mathrm{H}$ \& E. $1000 \times$.

the organs of choice for histological studies of chemically induced lesions (CoucH, 1975). These organs are easily damaged by low concentrations of numerous toxic and metabolic disturbances (CAHN, 1975; RoBERTS, 1978). The primary pathological changes we observed were found in fish exposed to $1.25 \mathrm{mg} / l \mathrm{KMnO}_{4}$, and higher concentrations.

Epithelial hyperplasia was suggested as an initial response of gills to toxicity following exposure to various pollutants. In this study, varying degrees of hyperplasia were observed. Gill hyperplasia was more uniform and extensive 


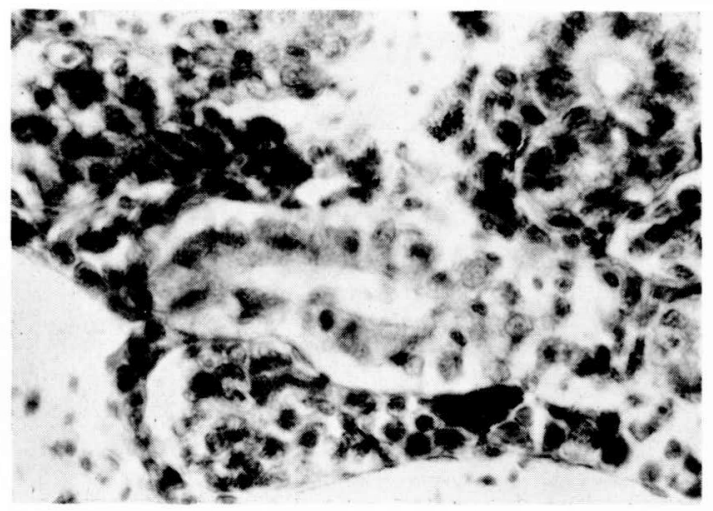

Fig. 17. Glomerulus shrunk after exposure to 1.25 $\mathrm{mg} / l \mathrm{KMnO}_{4}$ for $24 \mathrm{~h}$. H \& E. $1000 \times$.

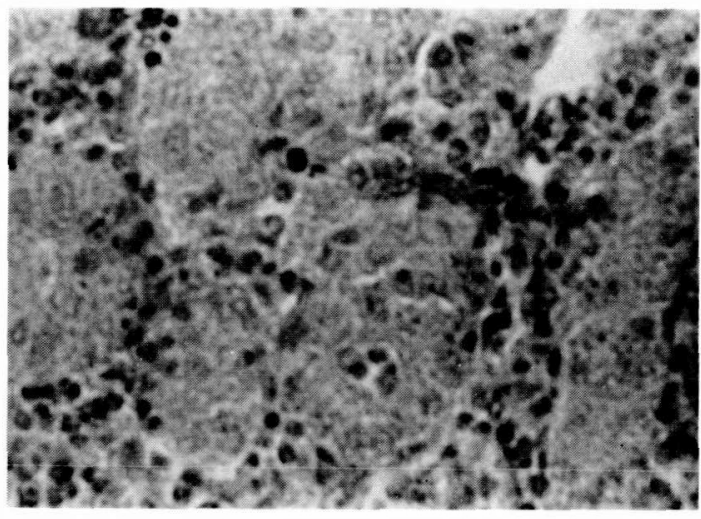

Fig. 18. Cloudy swelling of epithelial cells of renal tubules after exposure to $1.30 \mathrm{mg} / l \mathrm{KMnO}_{4}$ for $96 \mathrm{~h}$. $\mathrm{H} \& \mathrm{E} . \quad 1000 \times$.

in fish treated with concentrations higher than $1.40 \mathrm{mg} / l \mathrm{KMnO}_{4}$. Severe proliferation of epithelial cells which leads to fusion of adjacent lamellae decreases the surface area of the gills, and consequently, the ability of the animal to absorb oxygen (Burrows, 1964; GARDNER and YeVICH, 1970).

Another gill damage frequently reported in toxicity related studies is epithelial lifting. In our study, the respiratory epithelia lifted away in a continuous sheet from the pillar cell system. In severe cases, the epithelial layer was completely ruptured thereby exposing the capillaries to water. SKIDMORE and TOVELl (1972) suggested epithelial lifting as an acute inflammatory reaction to pollutants. Disruption of the epithelial layer has

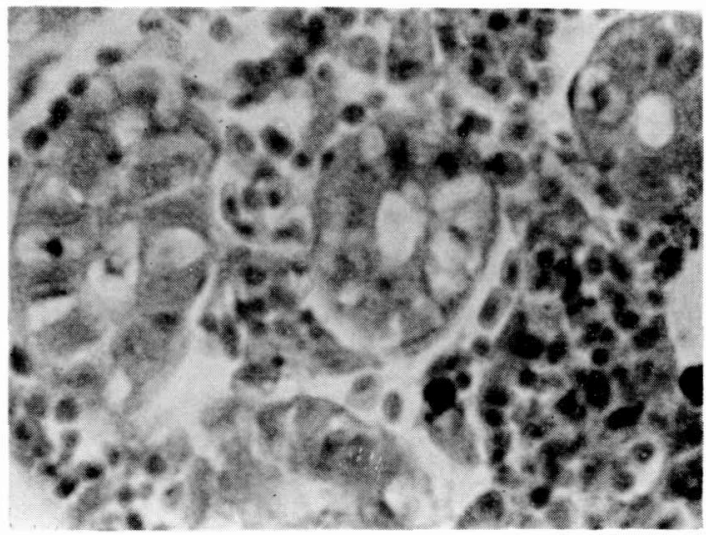

Fig. 19. Vacuolation of epithelial cells of renal tubules after exposure to $1.35 \mathrm{mg} / l \mathrm{KMnO}_{4}$ for $96 \mathrm{~h}$. H \& E. $1000 \times$

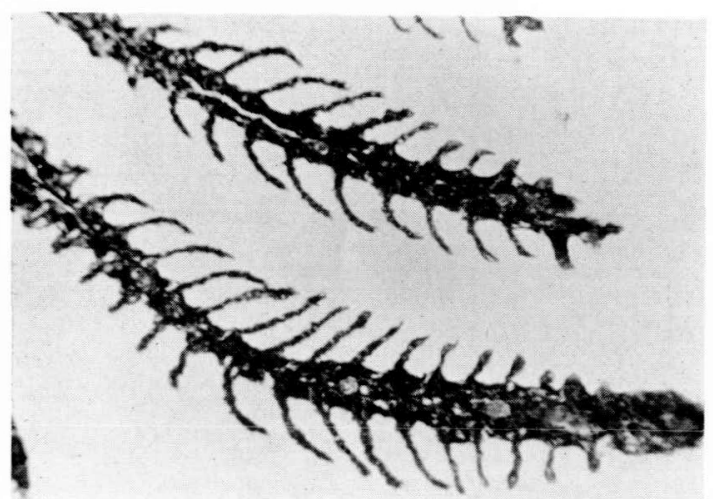

Fig. 20. Gill filaments after exposure to $1.0 \mathrm{mg} / l$ $\mathrm{KMnO}_{4}$ for $96 \mathrm{~h}$ and then maintained in untreated seawater for $240 \mathrm{~h}$. $\mathrm{H}$ \& E. $200 \times$.

been implicated in asphyxiation, partial or complete loss of secretory or excretory function, or to loss of plasma electrolytes or proteins from open or exposed gill lesions (Mitchell et al., 1978).

Gill lamellar telangiectasis has been suggested as a diagnostic lesion of fish associated with chemical pollution (ElLer, 1975; WALSH and RiBELIN, 1975; RoBERTS, 1978). In the present study, lamellar telangiectasis was observed in fish treated with $1.45 \mathrm{mg} / l \mathrm{KMnO}_{4}$ or higher concentration, and only after $96 \mathrm{~h}$ of exposure. Telangiectasis resulted to dilation of the capillary and pooling of the blood which thromboses and eventually fuses with the adjacent lamellae. If there 


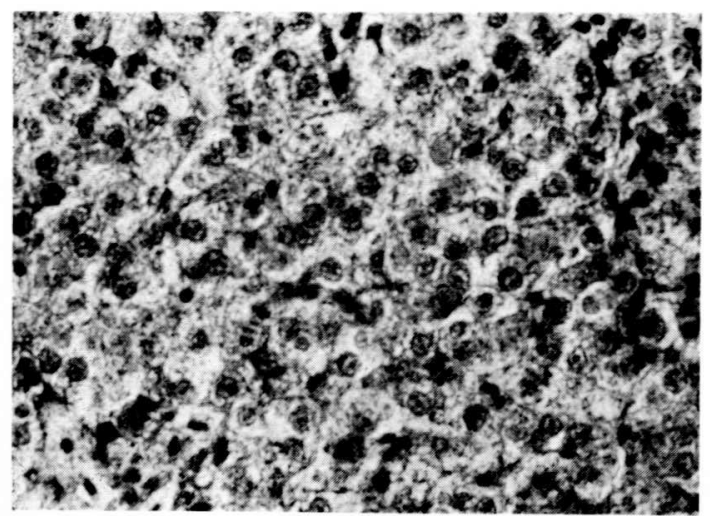

Fig. 21. Liver hepatocytes after exposure to 1.0 $\mathrm{mg} / l \mathrm{KMnO}_{4}$ and then maintained in untreated seawater for $240 \mathrm{~h}$. $\mathrm{H}$ \& $\mathrm{E}$. $1000 \times$

are several telangiectatic lamellae, respiratory function may be hindered, and if such fish are further traumatized, rupture or fatal hemorrhage may follow (ROBERTs, 1978).

Gill alterations are easily observed in chemically-induced studies designed to measure shortterm acute toxicity. In this study, the most consistent gill lesions were lamellar hyperplasia, fusion of adjacent lamellae, epithelial lifting, and lamellar telangiectasis. Such changes may be specific tissue reactions to toxicosis as noted in previous reports mentioned. Gill changes are often directly related to disorders in gill function which consequently may affect the physiology or cause the death of fish.

The liver pathology of fish is less diverse than that of the mammals (RoBerTs, 1978). The most common type of degenerative changes we encountered are vacuolation of the hepatocytes and focal necrosis. Vacuolation of the hepatocyte was common in all concentrations tested. The severity of cell vacuolation was related to concentrations of $\mathrm{KMnO}_{4}$. The large, smooth-edged vacuoles of the hepatic cells is a characteristic of advanced pathological response (CoUCH, 1975). Liver cell vacuolation is considered as the most common non-specific liver lesion found in toxic conditions and indicates abnormal accumulation of fats (Couch, 1975; RoBerTs, 1978). RobERTs (1978) associated degenerative fatty change of hepatocytes to unsuitable dietary fats. The disruption of the well-defined liver structure as a

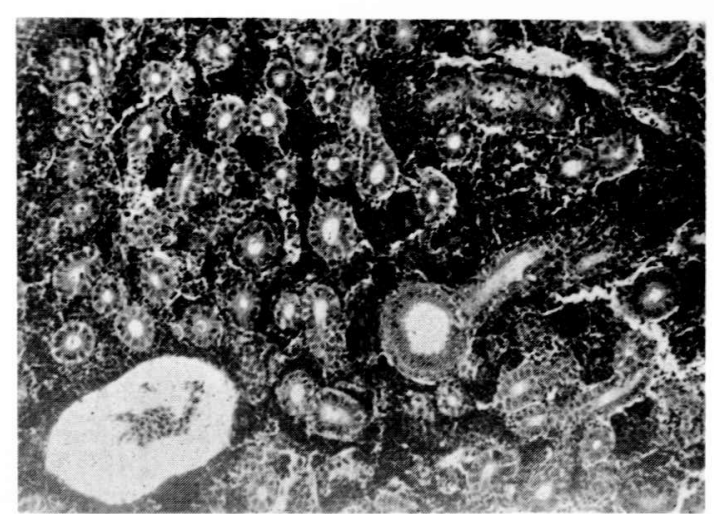

Fig. 22. Renal tubules after exposure to $1.25 \mathrm{mg} / \mathrm{l}$ $\mathrm{KMnO}_{4}$ for $96 \mathrm{~h}$ and then maintained in untreated seawater for $240 \mathrm{~h}$. $\mathrm{H}$ \& $\mathrm{E}$. $200 \times$.

consequence of cytoplasmic vacuolation is an indication of nutritional deficiency enhanced by toxic conditions (ELLER, 1971).

Necrosis of liver cells, pyknosis of hepatocyte nuclei, sinusoidal congestion, and fibrosis are also commonly observed in toxic conditions ( $\mathrm{COUCH}$, 1975; Roberts, 1978; Pierce et al., 1980).

The types of pathological changes in kidneys of milkfish exposed to $\mathrm{KMnO}_{4}$ were similar in all treatments. In this study, histopathologic lesions in kidney are confined mostly in the glomerulus and renal tubules. In pathological conditions, dilation of the glomerular capillaries and thickening of the walls occur as a result of alterations in the basal lamina (HiBIYA, 1982). This dilation and thickening with a consequent hypertrophy of the glomerulus have been reported in fishes with nutritional deficiencies (WATANABE et al., 1970; Yokоте, 1970), or fishes treated with alloxan (INUi and Yokote, 1975).

Degeneration or cloudy swelling of kidney tubules have been reported in several fish species following exposure to pesticides and heavy metals (KING, 1962; BuHLer et al., 1969; WALSH and Ribelin, 1975; HibIYA, 1982).

Results from this study indicate that although milkfish could tolerate as high as $1.40 \mathrm{mg} / \mathrm{l}$ $\mathrm{KMnO}_{4}$, tissue alterations were evident. Histologically, there was no difference between treatments, but the intensity of tissue damage increases with increasing concentration. However, sublethal pathological changes in fish tissues appear 
to be temporary, and once fish return to a $\mathrm{KMnO}_{4}$ free environment, they have the ability to recover.

\section{Acknowledgements}

This research was supported by the International Research Centre of Canada under Project No. 3-P-81-0171.

The authors wish to express their thanks to Ms. Margarita de la Cruz and the staff of Microtechnique Service Laboratory, SEAFDEC for their assistance.

\section{References}

American Public Health Association (1971): Standard Methods for Examination of Water and Wastewater, 13 th ed., American Public Health Assoc., Washington, $874 \mathrm{pp}$.

Buhler, D. R., M. E. Rasmusson and W. E. Shanks (1969): Chronic oral DDT toxicity in juvenile coho and chinook salmon. Toxicol. Appl. Pharmacol., 14, 535-555.

BURRows, R. E. (1964): Effects of accumulated exretory products of hatchery-reared salmonids. U.S. Fish. Wildl. Serv. Res. Rep., 66, 1-12.

CAHN, P. H. (1975): The pathology of the liver and spleen in naturally stressed Atlantic Menhaden, In "The Pathology of Fishes, ed., Ribelin', W. E. and G. Migaki, Univ. of Wisconsin Press, Madison, 1004 pp." 443-460.

Couch, J. A. (1975): Histopathological effects of pesticides and related chemicals on the livers of fishes, In "The Pathology of Fishes, ed. Ribelin, W. E. and G. Migaki, Univ. of Wisconsin Press, Madison, 1004 pp." 559-584.

Davis, J. C. (1973): Sublethal effects of bleached kraft pulp mill effluent on respiration and circulation in sockeye salmon (Onconrhychus nerka). $J$. Fish. Res. Bd. Can., 30, 369-377.

ElLeR, L. L. (1971): Histopathologic lesions in cutthroat trout (Salmo clarki) exposed chronically to the insecticide endrin. Amer. J. Pathol., 64, 321.

ELLER, L. L. (1975): Gill lesions in freshwater teleosts, In "The Pathology of Fishes, ed. Ribelin, W. E. and G. MigaKI, Univ. of Wisconsin Press, Madison, 1004 pp." 305-330.

Gardner, G. R. and P. P. Yevich. (1970): Histological and hematological responses of an estuarine teleost to Cadmium. J. Fish. Res. Bd. Can., 27, 2185-2196.

HibiYA, T. ed. (1982): An Atlas of Fish HistologyNormal and Pathological Features, Kodansha,
Tokyo, 147 pp.

INUI, Y. and M. Yokote. (1975): Gluconeogenesis in the eel-II. Gluconeogenesis in the alloxanized eel. Bull. Japan. Soc. Sci. Fish., 41. 291-300.

$J_{\mathrm{EE}}, \mathrm{L}$. K. and J. A. PlUmB. (1981): Effects of organic load on potassium permanganate as a treatment for Flexibacter columnaris. Trans. Amer. Fish. Soc., 110, 86-89.

KING, S. F. (1962): Some effects of DDT on the guppy and the brown trout. U.S. Fish. Wild. Serv. Spec. Sci. Rep. Fish., 399, 7-22.

LAY, B. A. (1971): Applications for potassium permanganate in fish culture. Trans. Amer. Fish. Soc., 100, 813-816.

MarkING, L. L. and T. D. Bills. (1975): Toxicity of potassium permanganate to fish and its effectiveness for detoxifying antimycin. Trans. Amer. Fish. Soc., 104, 579-583.

Meyer, F. P., R. A. Schnick, K. B. Cumming and B. L. BENGER. (1976): Registration status of fishery chemicals. Prog. Fish. Cult., 38, 3-7.

Mitchell, A. J., J. M. Grizzle and J. A. Plumb. (1978): Nifurpirinol (Furanace: P-7138) related lesions on channel catfish Ictalurus punctatus (Rafinesque). J. Fish Dis., 1, 115-121.

Phelps, R. P., J. A. Plumb and C. W. Harris. (1977): Control of external bacterial infections of blue. gills with potassium permanganate. Prog. Fish Cult., 39, 142-143.

Pierce, K. V., B. B. McCain and S. R. Wellings. (1980): Histopathology of abnormal livers and other organs of starry flounder Platichthys stellatus (Pallas) from the estuary of the Duwanish River, Seattle, Washington, U.S.A. J. Fish Dis., 3, 81-91.

RoBERTS, R. J. (1978): The Pathophysiology and Systematic Pathology of Teleosts. In "Fish Pathology ed. R. J. Roberts, Bailliere Tindall, London, 318 pp." 55-91.

Skidmore, J. F. and P. W. A. Tovell. (1972): Toxic effects of zinc sulfate on the gills of rainbow trout. Wat. Res., 6, 217-230.

THomas, R. E. and S. D. Rice. (1975): Increased opercular rates of pink salmon (Oncorhynchus gorbuscha) fry after exposure to the water soluble fraction of Crudhoe Bay crude oil. J. Fish. Res. Bd. Can. 32, 2221-2224.

TuCKer, C. S. and C. E. Body. (1977): Relationship between potassium permanganate treatment and water quality. Trans. Amer. Fish. Soc., 106, 481488.

Walsh, A.H. and W.E. Ribelin, (1975): The pathology of pesticide poisoning, In "The Pathology of Fishes, ed. Ribelin, W. E. and G. MigaKi, Univ. of Wisconsin Press, Madison, 1004 pp." 515-541. 
Watanabe, T., F. Takashima, C. Ogino and T. Yokote, M. (1970): Spontaneous diabetes in carp HiBIYA, (1970): Effects of $\alpha$-tocopherol deficiency found in fish farms-I. Pathological study. Bull. on carp. Bull. Japan. Soc. Sci. Fish., 36, 623-630. Freshwater Fish. Res. Lab., 20, 39-42. 